\title{
Response of ammonia oxidizing microbes to the stresses of arsenic and copper in two acidic alfisols
}

\author{
Gangavarapu Subrahmanyam ${ }^{\mathrm{a}, \mathrm{b}}$, Hang-Wei Hu ${ }^{\mathrm{a}}$, Yuan-Ming Zheng a , \\ Gattupalli Archana ${ }^{\mathrm{b}}$, Ji-Zheng He ${ }^{\mathrm{a}}$, Yu-Rong Liu ${ }^{\mathrm{a}, *}$ \\ a State Key Laboratory of Urban and Regional Ecology, Research Center for Eco-Environmental Sciences, Chinese Academy of Sciences, Beijing 100085, China \\ ${ }^{\mathrm{b}}$ Department of Microbiology and Biotechnology Centre, The Maharaja Sayajirao University of Baroda, Vadodara 390002, India
}

\section{A R T I C L E I N F O}

\section{Article history:}

Received 28 May 2013

Received in revised form 24 January 2014

Accepted 27 January 2014

Available online 25 February 2014

\section{Keywords:}

Acidic soils

Heavy metal contamination

Potential nitrification rate

Ammonia oxidizers

Ammonia oxidizing archaea

amoA gene

\begin{abstract}
A B S T R A C T
Soil pollution by elevated heavy metals exhibits adverse effects on soil microorganisms. Ammonia oxidizing bacteria and ammonia oxidizing archaea perform ammonia oxidative processes in acidic soils. However, influence of heavy metal stress on soil ammonia oxidizers distribution and diversity is inadequately addressed. This study investigated the responses of ammonia oxidizing bacteria and archaea to heavy metals, $\mathrm{Cu}$ and As during short-term laboratory experiment. Two different acidic alfisols named as Rayka and Hangzhou spiked with different concentrations of $\mathrm{As}, \mathrm{Cu}$ and $\mathrm{As}+\mathrm{Cu}$ were incubated for 10 weeks. Significant reduction in copy numbers of archaeal-16S rRNA, bacterial-16S rRNA and functional amoA genes was observed along elevated heavy metal concentrations. Ammonia oxidizing archaea was found to be more abundant than ammonia oxidizing bacteria in all the heavy metal treatments. The potential nitrification rate significantly decreased with increasing $\mathrm{As}$ and $\mathrm{Cu}$ concentrations in the two soils examined. Denaturing gradient gel electrophoresis analysis revealed no apparent community shift for ammonia oxidizing archaea even at higher concentrations of As and $\mathrm{Cu}$. Phylogenetic analysis of archaeal amoA gene from 4 clone libraries indicated that all the archaeal amoA sequences were placed within 3 distinct clusters from soil and sediment group 1.1b of Thaumarchaeota. Our results could be useful for the better understanding of the ecological effects of heavy metals on the abundance and diversity of soil ammonia oxidizers.
\end{abstract}

(c) 2014 Elsevier B.V. All rights reserved.

\section{Introduction}

Ammonia oxidation (AO) is the first and rate limiting step in nitrification (Di et al., 2009), and thus plays a decisive role in the global nitrogen cycle. For more than a century, it has been believed that AO is exclusively mediated by chemolitho-autotrophic ammonia oxidizing bacteria (AOB) (De Boer and Kowalchuk, 2001). The recent discovery of homologs of ammonia monooxygenase gene $(a m o A)$ in archaea and subsequent cultivation of autotrophic ammonia oxidizing archaea (AOA) affiliates to phylum Thaumarchaeota has shown the importance of AOA in the global nitrogen cycle (Könneke et al., 2005). Nevertheless, the key factors driving the abundance, diversity and activity of ammonia oxidizers are still unclear. Studies have demonstrated the changes in abundance and diversity of $\mathrm{AOB}$ and $\mathrm{AOA}$ in response to different abiotic stresses like temperature, $\mathrm{pH}$, soil type, organic and inorganic fertilization (Chan et al., 2013; Chen et al., 2013; He et al., 2007; Nicol

\footnotetext{
* Corresponding author. Tel.: +8610 62849500; fax: +861062923563.

E-mail address: yrliu@rcees.ac.cn (Y.-R. Liu)
}

et al., 2008; Nyberg et al., 2012). However, the response of AOA to heavy metals in acidic soils remains poorly characterized. It has been estimated that over $50 \%$ of the world's potential arable lands are acidic (von Uexkull and Mutert, 1995). Currently about $12 \%$ of world land area in crop production is acidic in nature. Asian continent accounts for approximately 1044 million ha (26.4\%) of the world's acidic soils. It is of paramount importance to know the effect of anthropogenic perturbations on nutrient cycling processes of acidic soils. For example, soil contamination by heavy metals is known to be one of the most important anthropogenic perturbations and is of great worldwide concern. Heavy metals adversely affect the activity and diversity of microbial community associating with soil elemental cycling (Dai et al., 2004; Khan et al., 2010). Among all metals, copper $(\mathrm{Cu})$ and $\operatorname{arsenic}(\mathrm{As})$ have received much attention because of their high toxicity and solubility in agricultural soils (Sheldon and Menzies, 2005; Smedley et al., 1996). In addition to this, As has received a lot of attention in East and Southeast Asia because of the well-publicized catastrophes in India (West Bengal), Bangladesh, and Vietnam (Meharg and Hartley-Whitaker, 2002; Singh and Ma, 2007). Cu enters the soils due to several sources, e.g. mining, smelting, electroplating, biosolids, agricultural 
application of sludge, copper-containing pesticides and fertilizers (Lone et al., 2008). Elevated levels of As in soils on the other hand originate from the widespread use of arsenicals as pesticides, primary and secondary industrial inputs (Adriano, 2001). Numerous field and microcosm studies have demonstrated the adverse effects of As and $\mathrm{Cu}$ on soil microbial communities (Brandt et al., 2006; Chodak et al., 2013; Wightwick et al., 2013). However, little information is available on the effects of $\mathrm{Cu}$ and As on soil ammonia oxidizers (especially in acidic soils) which are an important functional groups within the $\mathrm{N}$ cycle.

Nitrification is an important soil function that could be reduced by heavy metals and therefore considered as sensitive microbial process with regards to heavy metal stress (Smolders et al., 2001). Studies have particularly emphasized the response of ammonia oxidizing bacteria to heavy metals such as $\mathrm{Zn}, \mathrm{Cu}$ and $\mathrm{Hg}$ (Lee et al., 2011; Liu et al., 2010; Mertens et al., 2009; Vasileiadis et al., 2012). Some of these studies reported a sensitive response of the AOB community to heavy metals (Frey et al., 2008; Lee et al., 2011; Vasileiadis et al., 2012); AOA, on the other hand, appear to be tolerant to the stress of heavy metal such as $\mathrm{Hg}$ and Zn (Liu et al., 2010; Vasileiadis et al., 2012). Previously, AOA-amoA gene diversity profile in heavy metal polluted soils has been established by DGGE and T-RFLP based community shifts (Mertens et al., 2009; Ollivier et al., 2012; Vasileiadis et al., 2012). However, these studies could not offer detailed AOA phylogenetic information such as what are the AOA in heavy metal polluted soils. Moreover, little information is available on the responses of ammonia oxidizers to As and $\mathrm{Cu}$ in acidic soils, where AOA are considered to be a main contributor to ammonia oxidization (Lee et al., 2011; Zhang et al., 2012).

The objective of the present study was to assess the responses of ammonia oxidizing microbes (AOA and $\mathrm{AOB}$ ) to the $\mathrm{Cu}$ and $\mathrm{As}$ stresses particularly in acidic soils after 10 weeks of incubation. The effects of heavy metal on abundance and community diversity were studied based on the q-PCR, DGGE and clone library sequencing analysis. The results may help to improve our understanding of the ecological effects of heavy metals on the abundance and diversity of ammonia oxidizers in acidic alfisols.

\section{Experimental procedures}

\subsection{Soil samples and experimental setup}

Two different types of pristine alfisols (from both India and China) were collected for short-term incubation experiments. Triplicate composite sampling was performed for soil collection. In brief, each top soil sample $(10 \mathrm{~cm}$ in depth) was composed by pooling three subsamples obtained in a $1 \times 1-\mathrm{m}$ area. Alfisol-RA was collected from Rayka, a site located in semiarid region near the Mahi River basin, Gujarat, western India. 'RA' is an oligotrophic silty-loam soil, with low organic matter $(0.86 \%)$, low moisture content $(8 \%$, equivalent to $40 \%$ of maximum WHC) and $\mathrm{pH}$ of 5.1 . Alfisol-HZ was collected from Hangzhou, Zhejiang province, eastern China. 'HZ' alfisol is a clay loam, consisting of relatively more organic matter (2.88\%) with a moisture content of $18.9 \%$ (equivalent to $55 \%$ of maximum WHC) and a pH of 5.6. The observed field values of $\mathrm{NH}_{4}{ }^{+}-\mathrm{N}$ for RA and $\mathrm{HZ}$ soils at the time of sampling were $9.05( \pm 2.38)$ and $9.37( \pm 1.72) \mathrm{mg} \mathrm{kg}^{-1}$ dry soil, respectively. The $\mathrm{Cu}$ concentrations in these soils ( $4.2 \mathrm{mg} \mathrm{kg}^{-1}$ dry soil in $\mathrm{HZ}$ and $8.6 \mathrm{mg} \mathrm{kg}^{-1}$ dry soil in RA) were below the permissible limits established by the Indian Standard guidelines, while As was not detected in any of the soils.

We constructed series of short-term laboratory experiments with well mixed samples of RA and HZ (Liu et al., 2010). Soil samples were ground to a size finer than $2.5 \mathrm{~mm}$ and stored at $4{ }^{\circ} \mathrm{C}$. Before conducting the incubation experiments, soils moisture content was adjusted to the original soil moisture content at the time of sampling (40\% WHC for RA soils and 55\% WHC for $\mathrm{HZ}$ soils). Two different series of short-term experimental setups were constructed with RA and $\mathrm{HZ}$ soils. Three different types of metal treatments viz. As-spiked, Cu-spiked and combination of As and $\mathrm{Cu}$-spiked $(\mathrm{As}+\mathrm{Cu}$ ) were chosen for each short-term experimental series (RA and $\mathrm{HZ}$ series). Soil without addition of heavy metal contamination was considered as background control treatment (CK). Aqueous solutions of $\mathrm{CuCl}_{2}$ (Sigma-Aldrich, $\geq 99.9 \%$ purity) and $\mathrm{Na}_{2} \mathrm{HAsSO}_{4} \cdot 7 \mathrm{H}_{2} \mathrm{O}$ (Sigma-Aldrich $\geq 98 \%$ purity) were used as source of $\mathrm{Cu}$ and $\mathrm{As}$, respectively, and $\mathrm{pH}$ of the soils maintained to their natural values. The type of experimental design was completely randomized block. In $\mathrm{Cu}$ amended experiments the final concentrations of $\mathrm{Cu}$ were adjusted to $0,125,250$ and $500 \mathrm{mg} \mathrm{kg}^{-1}$ dry soil, while in As amended soils the concentrations were adjusted to $0,17.5,35$, and $70 \mathrm{mg} \mathrm{kg}^{-1}$ dry soil. Concentrations for combined As and $\mathrm{Cu}(\mathrm{As}+\mathrm{Cu})$ treatment were as follows: As$35+\mathrm{Cu}-250, \mathrm{As}-35+\mathrm{Cu}-500, \mathrm{As}-70+\mathrm{Cu}-250$ and $\mathrm{As}-70+\mathrm{Cu}-500$. Short-term experiments were named according to their nominal As and $\mathrm{Cu}$ concentrations. A total of $20 \mathrm{~g}$ (dry weight) of each sample was placed in a $200 \mathrm{ml}$ plastic jar. For each concentration of heavy metal three independent replicates were performed. The experimental setups were incubated at $25^{\circ} \mathrm{C}$ for 10 weeks in the dark. The samples were destructively harvested at the end of 10 th week.

\subsection{Soil chemical analysis and potential nitrification rates (PNRs)}

Soil chemical characteristics were analyzed before and after incubation periods. Soil gravimetric water content was determined after drying $10 \mathrm{~g}$ subsamples at $105^{\circ} \mathrm{C}$ for $24 \mathrm{~h}$. Soil pH was measured at the soil to water ratio of $1: 2.5$ and soil organic matter content was determined with $\mathrm{K}_{2} \mathrm{Cr}_{2} \mathrm{O}_{7}$ oxidation method. Soil samples were digested with $\mathrm{HNO}_{3}+\mathrm{HCl}(10 \mathrm{ml}, 1: 1 \mathrm{v} / \mathrm{v})$ for analysis of heavy metals by ICP-OES (PerkinElmer, California, USA). Soil ammonium and nitrate contents were extracted from fresh soil samples with $2 \mathrm{M} \mathrm{KCl}$ and determined by a continuous flow analyser (SAN++, Skalar, Holland). Particle size distribution was measured using the rapid sieving procedure. PNRs were measured using the chlorate inhibition method (Kurola et al., 2005). All the analysis was performed in triplicate samples and values are represented as mean value $(n=3)$ with standard error.

\subsection{Soil DNA extraction and quantification of genes by real-time quantitative PCR ( $q-P C R)$ assays}

DNA was extracted from $0.5 \mathrm{~g}$ of soil samples using Ultraclean $^{\mathrm{TM}}$ soil DNA Isolation Kits (MoBio Laboratory, Carlsbad, CA, USA). Abundance of bacterial-16S rRNA, archaeal-16S rRNA, bacterial-amo $A$ and archaeal-amo $A$ genes was determined by qPCR with the iCycler iQ5 thermocycler (Bio-Rad, Hercules, CA, USA) by the method described by Zhang et al. (2009). Quantification of bacterial-16S rRNA gene was performed using primers BACT1369F/PROK1541R and probe TM1389F (Suzuki et al., 2000). Primers A364Af and A934bR were used for quantification of archaeal-16S rRNA genes (Kemnitz et al., 2005). Primers ArchamoAF/Arch-amoAR (Francis et al., 2005) and amoA1F/amoA2R (Rotthauwe et al., 1997) were used for quantification of archaealamoA genes and bacterial-amoA genes, respectively, with $\mathrm{SYBR}^{\circledR}$ Premix Ex Taq ${ }^{\mathrm{TM}}$ (TaKaRa). Detailed thermal profiles of all the primers as well as standard curves for q-PCR were reported in earlier studies (He et al., 2007; Shen et al., 2008).

\subsection{Denaturing gradient gel electrophoresis (DGGE) analysis}

DGGE of archaeal-amoA gene community was performed with a DCode Universal Mutation Detection System (Bio-Rad, Germany). Archaeal-amo $A$ genes were amplified using primers Cren-amoA23f 
and Cren-amoA616r (Tourna et al., 2008). DGGE was performed as described by Zhang et al. (2010). After the electrophoresis, the gels were stained by 1:10,000 SYBR Gold Nucleic Acid Gel Stain (Invitrogen-Molecular Probes, Eugene, OR, USA) for 30 min according to the manufacturer's instructions, scanned by a GBOX/HR-E-M (Syngene, UK) and analyzed for diversity indices using the AlphaEase FC software (Alpha Innotech, CA, USA). The experiment was repeated twice to confirm the reproducibility.

\subsection{Construction of AOA-amoA gene clone library and sequencing analysis}

In order to investigate the detailed phylogenetic information of $\mathrm{AOA}$ in $\mathrm{Cu}$, As and combination of $\mathrm{Cu}+\mathrm{As}$ amended soils, four distinct soil treatments (CK, Cu-500, As-70, and As-70+ $\mathrm{Cu}-500$ ) were selected and the DNA extracted from three independent replicate samples were mixed. A total of 4 Thaumarchaeal AOA-amoA clone libraries (named as $1 \mathrm{~A}, 2 \mathrm{~A}, 3 \mathrm{~A}$, and $4 \mathrm{~A}$ ) were constructed. These included 1A: AOA-amoA gene clone library constructed from CK soil; 2A: AOA-amoA clone library constructed from As70; 3A: AOA-amoA clone library constructed from $\mathrm{Cu}-500$ and
4A: AOA-amoA clone library constructed from As-70+Cu-500. The products of archaeal-amoA genes amplified with the primers Arch-amoAF/Arch-amoAR (Francis et al., 2005) were purified with Wizard $^{\circledR}$ SV Gel and PCR Clean-Up System (Promega, Madison, WI, USA). The purified PCR products were ligated into the pGEMT Easy Vector (Promega, Madison, WI, USA), and the resulting ligation mix transformed into Escherichia coli JM109 competent cells following the manufacturer's protocol. About 100 positive clones for each AOA-amoA gene library were sequenced. A total of $400 \mathrm{AOA}-a m o A$ gene sequences were obtained from 4 clone libraries and the sequences were proceeded for further phylogenetic analysis. All the sequences were subjected to BLAST analysis in the NCBI GenBank database. Phylogenetic tree was constructed by MEGA 5.05 . Analysis of clone libraries was performed with Mothur v.1.27.0 (http://www.mothur. org, v. 1.22.1; Schloss et al., 2009). Rarefaction curves were generated and operational taxonomic units (OTUs) are defined as clusters of sequences with a similarity of $97 \%$ (i.e. a distance cutoff 0.03 ). All the 400 AOA-amoA gene sequences obtained in the study were deposited in GenBank nucleotide sequence database under accession numbers JX416592 to JX416690 and JX427105 to JX427403.
A:

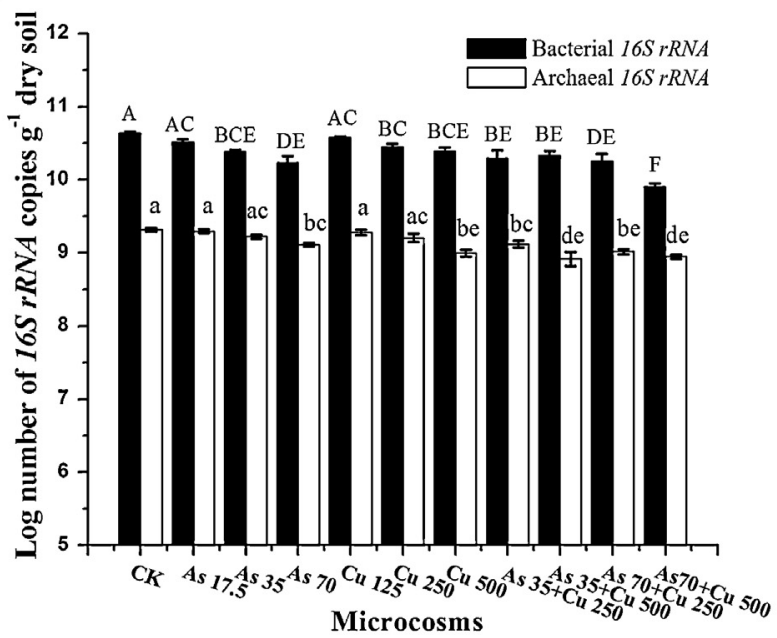

C:

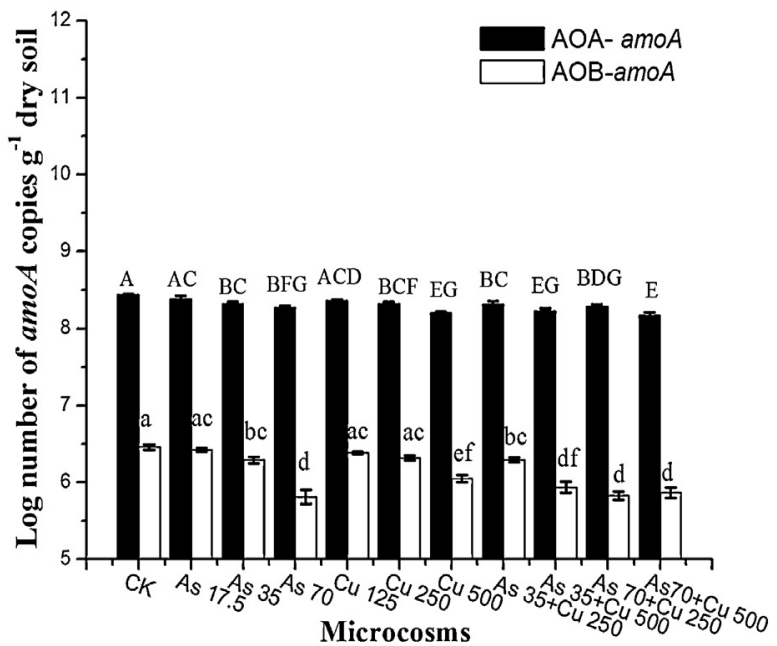

B:

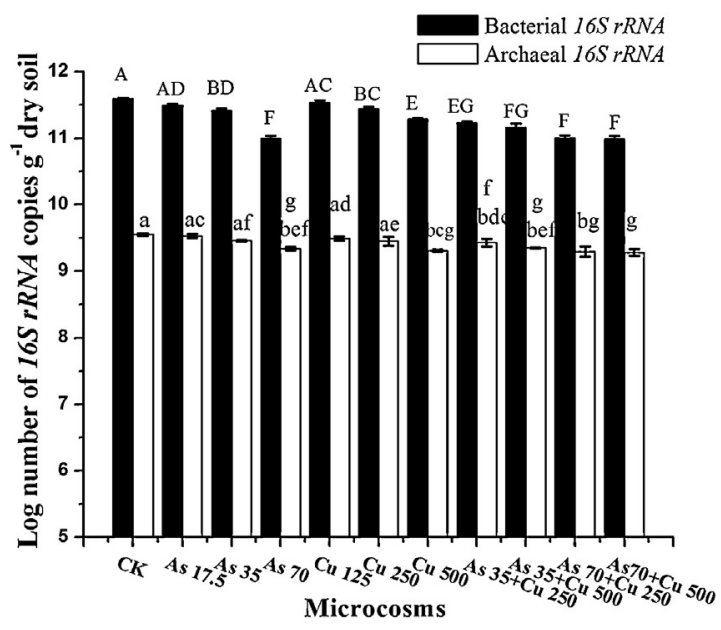

D:

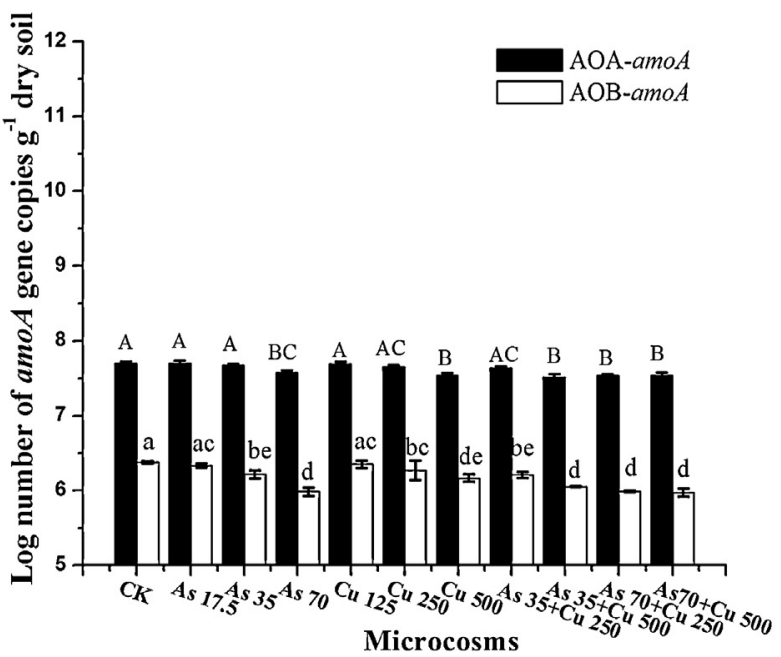

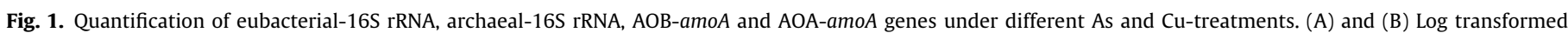

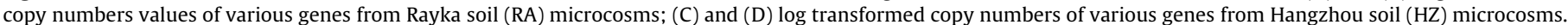

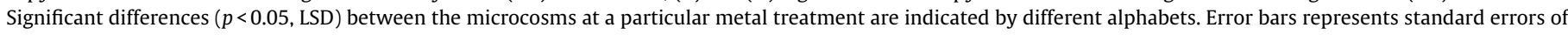
mean $(n=3)$. Treatments were named as for their nominal metal concentrations. CK stands for control treatment soil. 


\subsection{Statistical analysis}

Prior to statistical analysis, copy numbers of the genes were log transformed and normalized. Statistical analyses were performed using SPSS version 15.0 and SigmaPlot version 10.0. Pairwise comparisons of all the treatment means were conducted with one-way analysis of variance (ANOVA) by Fishers least significant difference test (LSD). Quantitative differences of two different groups were compared by $t$-test and $p<0.05$ was considered to be statistically significant. In order to describe the median effective concentration (EC50), linear regression was performed with normalized data and fitted in to a logistic response equation $\left\{y=a / 1+\left(x / x_{50}\right) b\right\}$ as described previously (Liu et al., 2010).

\section{Results}

\subsection{Effects of As and Cu on gene abundance in RA alfisols}

Among all the genes quantified, $\mathrm{AOB}-a \mathrm{moA}$ and bacterial-16S rRNA genes were highly sensitive to both metals (As and $\mathrm{Cu}$ ) in all treatments. The bacterial-16S rRNA gene copy numbers were lower in the As-amended soils than those in the $\mathrm{Cu}$-amended soils (Fig. 1A). Copy number of bacterial-16S rRNA gene in CK soil, was $4.3 \times 10^{10}$ copies $^{-1}$ dry soil, whereas the number significantly reduced in As-70 (7\%), Cu-500 (5.03\%) and As-70 + Cu-500 (6.9\%) soils (Table 1). AOA-amoA gene abundance ranged from $1.5 \times 10^{8}$ (in As-70+Cu-500) to $2.71 \times 10^{8}$ (in $\mathrm{CK}$ ) copies $\mathrm{g}^{-1}$ dry soil, and AOB-amoA gene abundance ranged from $6.78 \times 10^{5}$ (in As-70 $+\mathrm{Cu}-$ 500 ) to $2.9 \times 10^{6}$ (in $\mathrm{CK}$ ) copies $\mathrm{g}^{-1}$ dry soil (Fig. $1 \mathrm{~B}$ ). AOA-amoA gene copy numbers were significantly higher than that of $A O B-$ amoA gene in the As and $\mathrm{Cu}$-treated as well as in the $\mathrm{CK}$ soils (Fig. 1B).

\subsection{Effects of As and $\mathrm{Cu}$ on gene abundance in $\mathrm{HZ}$ alfisols}

Bacterial-16S rRNA gene ranged from $9.87 \times 10^{10}$ (in As-70 + Cu500 ) to $3.89 \times 10^{11}$ (in CK) copies $g^{-1}$ dry soil (Fig. 1C). When compared to CK, bacterial-16S rRNA gene copy numbers reduced by $5.14 \%, 2.61 \%$ and $5.18 \%$ in the As-70, Cu-500 and $\mathrm{As}-70+\mathrm{Cu}-$ 500 treatments, respectively (Table 1 ). AOA-amoA gene abundance ranged from $3.4 \times 10^{7}$ (in As-70+Cu-500) to $5.08 \times 10^{7}$ (in CK) copies $\mathrm{g}^{-1}$ dry soil, whereas AOB-amoA gene ranged from $9.5 \times 10^{5}$ (As-70 $+\mathrm{Cu}-250$ ) to $2.4 \times 10^{6}$ (in CK) copies $g^{-1}$ dry soil (Fig. 1D). Similar to RA microcosms, AOA-amoA gene abundance in $\mathrm{HZ}$ soils was significantly greater than that of AOB-amoA gene (Fig. 1D).

\subsection{Potential nitrification rates (PNRs) and their correlations with ammonia oxidizers}

The PNR significantly decreased with increasing As and Cu concentrations in both the soils (Table 2, Fig. S1). The highest PNR was noticed in CK-soils whereas the lowest PNR was observed in the As-70 and As-70+Cu-500 soils. The EC50-PNR is the concentration of heavy metal that inhibits potential nitrification process by $50 \%$ of its control value. HZ soils had the higher EC50-PNR values than RA soils. The EC50-PNR values of As for RA and HZ soils were determined to be $61.79( \pm 14.26)$ and $85.73( \pm 4.26)$, respectively, whereas the EC50-PNR values of $\mathrm{Cu}$ for RA and $\mathrm{HZ}$ soils were found to be $430( \pm 6.9) \mathrm{mg} \mathrm{kg}^{-1}$ and $557( \pm 119.3) \mathrm{mg} \mathrm{kg}^{-1}$, respectively. Both archaeal and bacterial ammonia oxidizers were positively correlated with PNR of heavy metal treated acidic soils; however the relation was much prominent with AOA of RA soils (Fig. 2). Comparatively AOA-amoA gene had a higher positive correlation than AOB to soil PNR at every metal concentration including in control soil (Table S1).

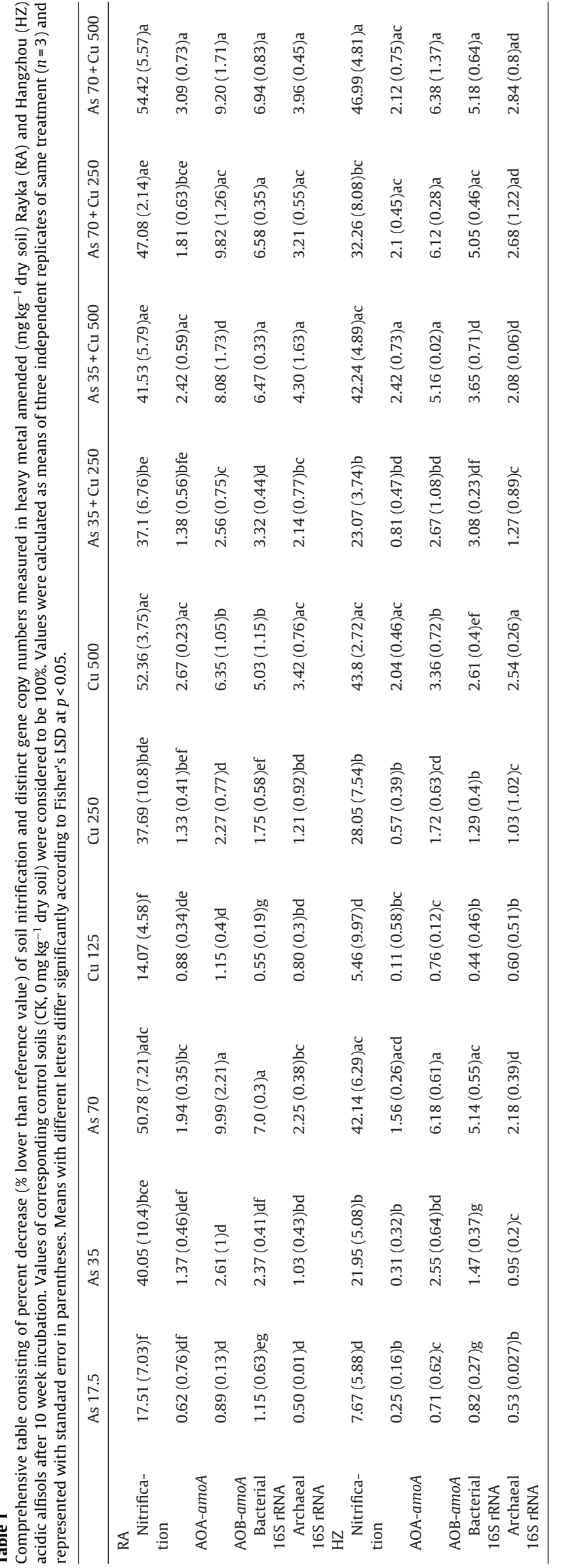



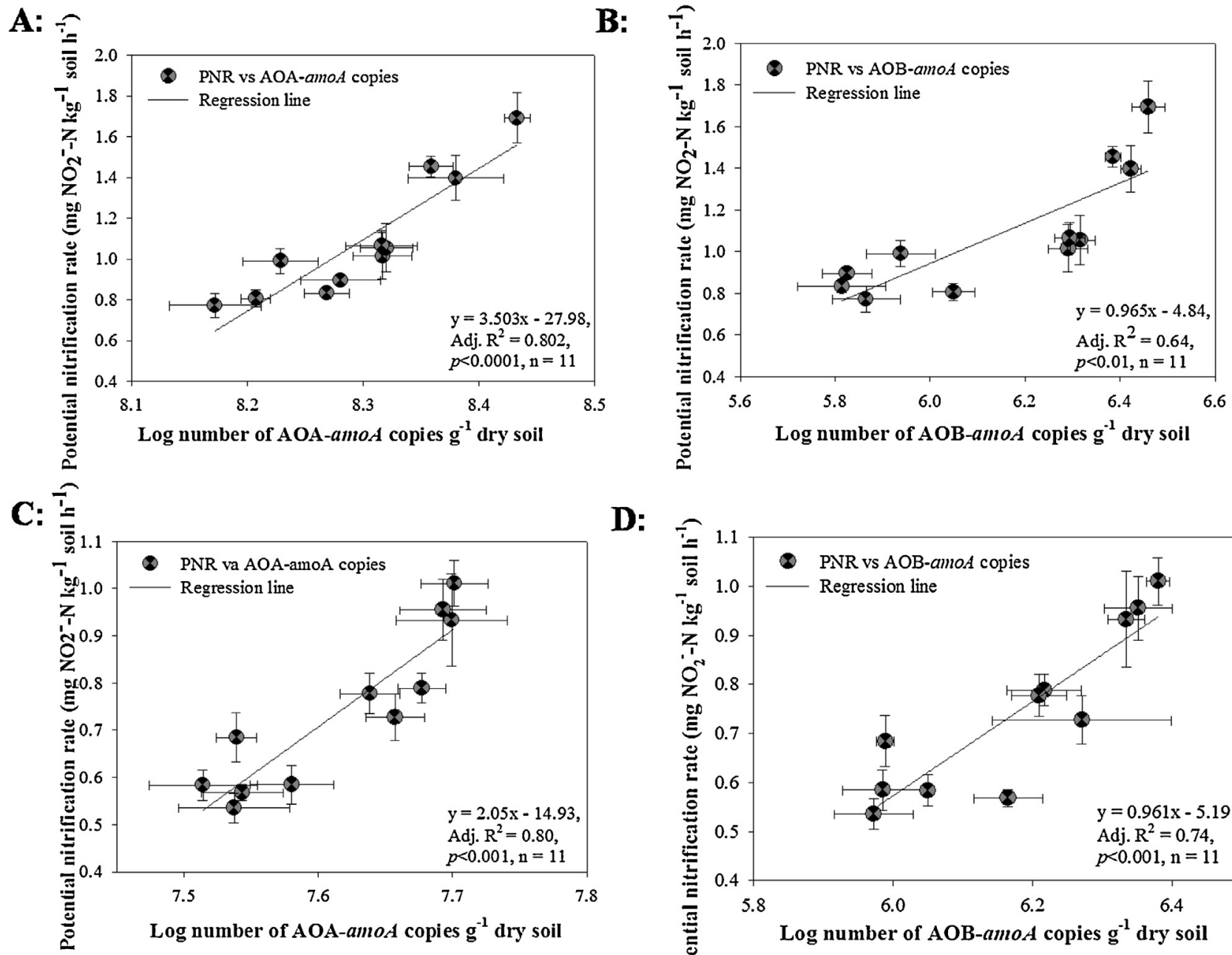

D:

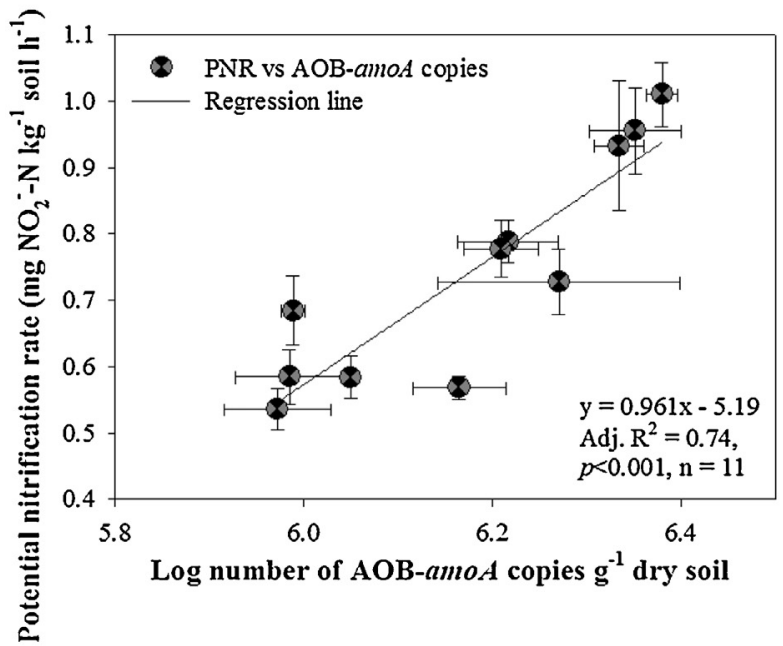

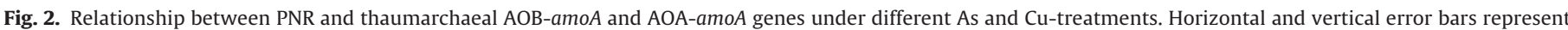

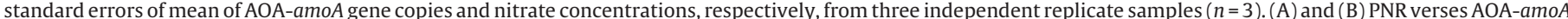

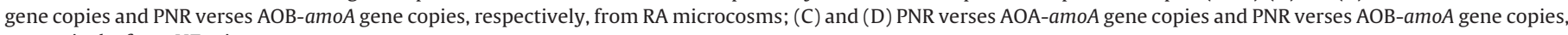
respectively, from $\mathrm{HZ}$ microcosms.

\subsection{Community shift of $A O A$}

DGGE profiles of AOA-amoA genes of both RA and $\mathrm{HZ}$ soils are shown in Fig. 3A and B, respectively. In both RA and $\mathrm{HZ}$ soils, AOA population showed no apparent community shift in response to heavy metals amendment (As, $\mathrm{Cu}$ and $\mathrm{As}+\mathrm{Cu}$ ). Pollution specific AOA community patterns were not detected by comparison of DGGE profiles. No significant differences amongst AOA-amoA gene diversity indices were noticed in the heavy metal amended and control (CK) soils. Relatively, RA soils possessed higher diversity indices. AOA-amoA gene richness $(H)$ and evenness $(E)$ of RA soils ranged from 2.03 to 2.18 and 1.84 to 2.02 , respectively; whereas, these values for $\mathrm{HZ}$ soils ranged from 1.26 to 1.55 and 1.17 to 1.5 , respectively. Range weighted richness $(R r)$ for the samples were found to be stable and the values for RA and $\mathrm{HZ}$ were found to be 53.28 and 54.08 , respectively.

\subsection{AOA-amoA gene clone library and phylogenetic analysis}

Phylogenetic analysis showed that all the AOA-amoA gene sequences were placed within three distinct clusters likely from soil and sediment origin (Fig. 4). Cluster-III was the dominant group containing $51-60 \%$ of total sequences, whereas cluster-II was found to be less abundant and consisted of $14 \%$ to $20 \%$ of total sequences. All these sequences were found to be affiliated with only group $1.1 \mathrm{~b}$ lineage. There was no major difference among AOA-amoA gene phylogeny of 4 clone libraries however, notably two changes were associated with cluster-I under group 1.1b. Firstly, one particular OTU showing absolute representative of acidic paddy soil clone (HQ215926.1) was highly distributed in metal treated soils only (Fig. 4). Secondly, OTU under representation of Indian Ocean sediment clone (JN190688.1) was only distributed in CK-soil clone library. Rarefaction analyses of all 4 AOA-amoA libraries yielded asymptotic curves (Fig. S2). A distance of 0.03 used to define phylotypes and 18 to 22 OTUs are observed among 4 clone libraries (Table S2, Fig. S2).

\section{Discussion}

Soil ammonia oxidizing archaea (AOA) have been suggested to be more stable and abundant than ammonia-oxidizing bacteria (AOB) in acidic soils (He et al., 2012; Zhang et al., 2012). However, their relative distribution and potential contribution under contrasting environmental conditions are unclear. In the present study response of ammonia oxidizing microbes to the stresses of As and $\mathrm{Cu}$ were investigated in acidic soils. The findings demonstrated 


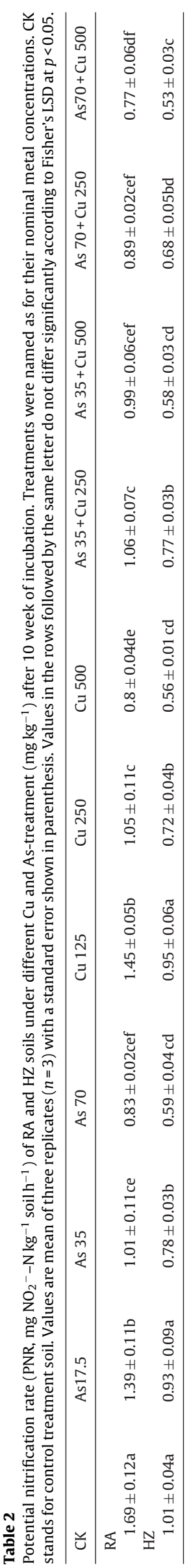

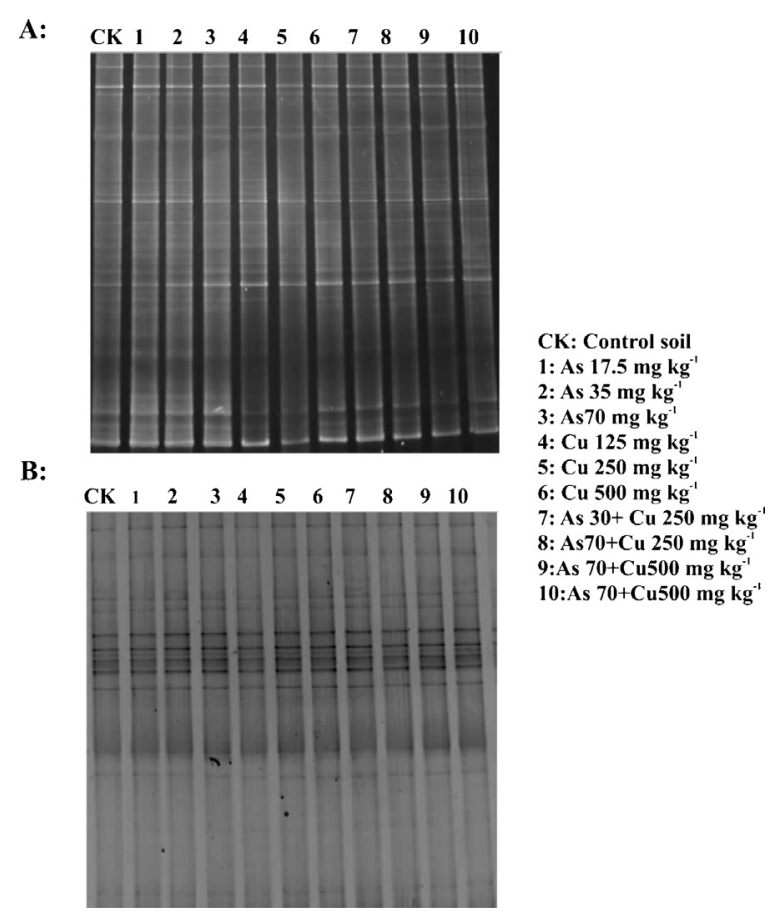

Fig. 3. Denaturant gradient gel electrophoreses (DGGE) analysis of thaumarchaeal AOA- $a m o A$ gens under different As and Cu-treatments. (A) Thaumarchaeal AOAamoA community structure under RA microcosms; (B) thaumarchaeal AOA-amoA community structure under $\mathrm{HZ}$ microcosms. Lane numbers indicates different As and $\mathrm{Cu}$-treatments.

that As and $\mathrm{Cu}$ adversely affected the abundance and activity of ammonia oxidizers in acidic alfisols and decreased soil nitrification potential. These results suggest that soil contamination by As and $\mathrm{Cu}$ may have a significant impact on microbial mediated soil $\mathrm{N}$-transformations.

In this study, abundance of bacterial and archaeal-16S rRNA genes showed contrasting responses to the stress of heavy metals. Higher reduction in bacterial amoA gene copies were observed in As amended soils, while grater reduction of archaeal amo $A$ gene copies were found in $\mathrm{Cu}$ amended soils. Thus, it could be inferred that archaeal and bacterial ammonia-oxidizers may occupy different niches in metal polluted acidic soils. These results are in concordance with earlier findings where specific niche preference of AOA and $\mathrm{AOB}$ was observed in contrasting acidic soil physiochemical gradients (He et al., 2012; Li et al., 2009; Zhang et al., 2012). The abundance of both AOA and AOB-amoA genes was comparable to those observed in previous studies wherein greater abundance of the AOA-amoA gene was noticed compared to the bacterialamoA gene in most of the arable acidic soils (He et al., 2007, 2012; Leininger et al., 2006; Nicol et al., 2008; Zhang et al., 2010), agricultural soils (Chan et al., 2013) and in $\mathrm{Cu}$ amended grassland soils (Li et al., 2009). Among all the metal treatments, combined As + Cu treatment had comparatively higher impacts on the ammonia oxidizers abundance compared to the treatments with As and $\mathrm{Cu}$ individually.

In this study, higher abundance of AOA-amoA over AOB-amoA genes in the heavy metal polluted soils indicated a possible metal tolerance and adaptability of AOA. Li et al. (2009) reported similar kind of observation in $\mathrm{Cu}$ amended neutral and alkaline grassland soils where AOB-amoA gene was reduced 107-232 fold while AOAamoA gene reduction was found to be $10-89$ fold. Metal tolerance of AOA could be attributed to integrity and stability of archaeal membrane under chronic stresses (Schleper et al., 2005). It is reported that archaea membranes are less permeable to ions than bacterial 


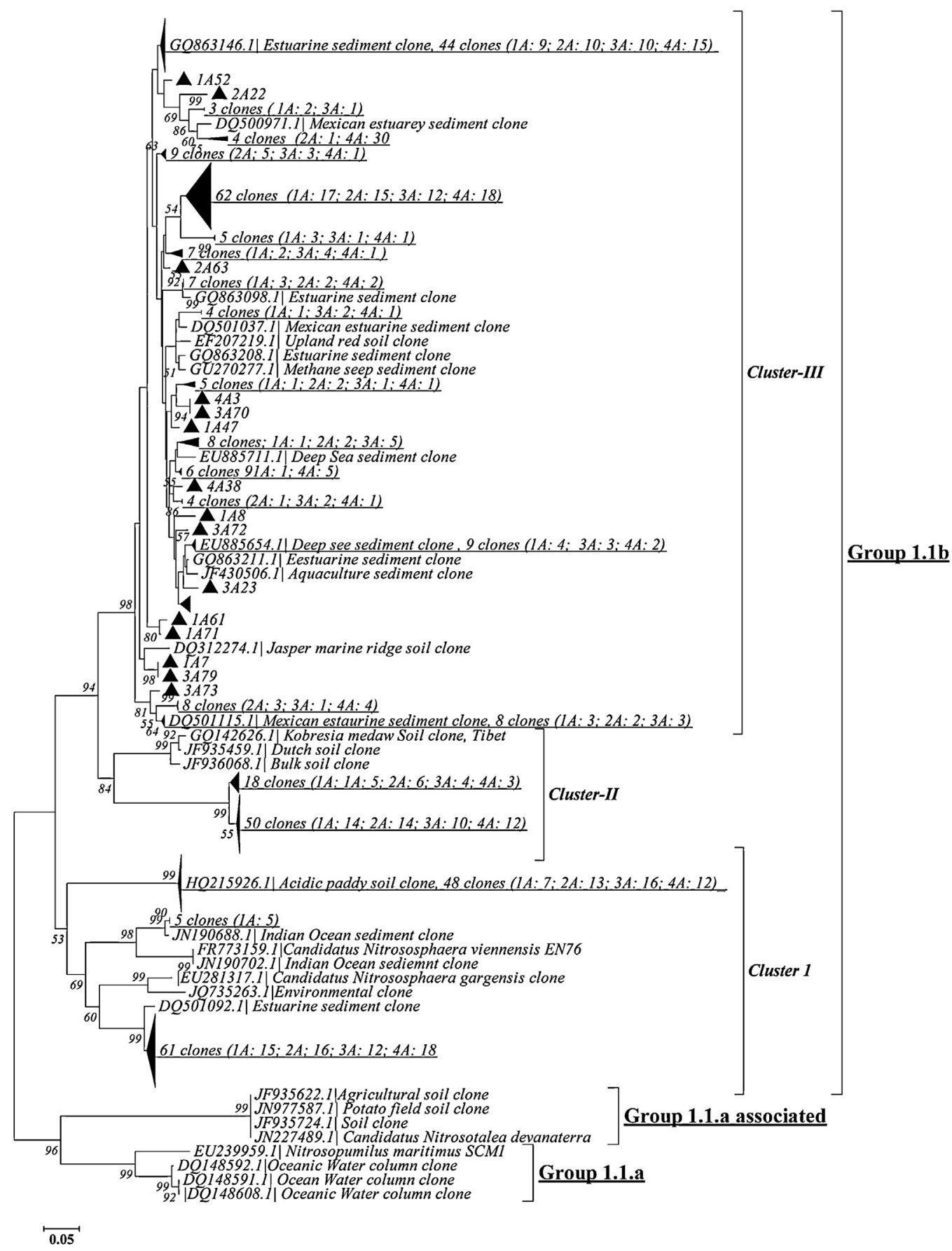

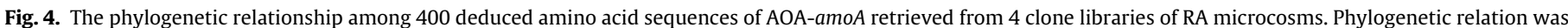

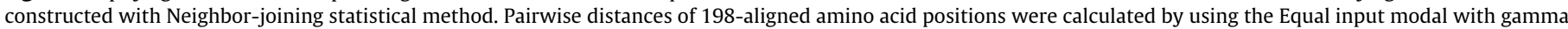

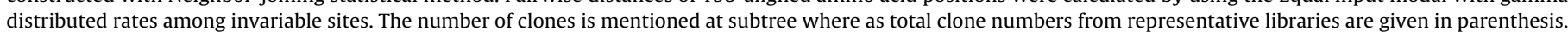

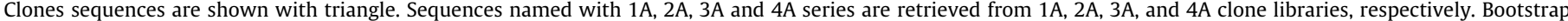

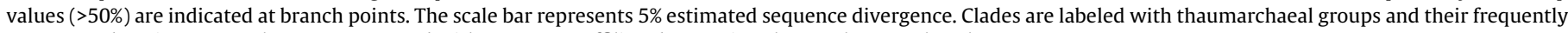
represented environment. The tree was rooted with sequences affiliated to marine cluster, thaumarchaeal group 1.1a.

membranes due to exceptional chemical structure of their membrane lipids (Gabriel and Chong, 2000; Kandle and König, 1998). Recent whole genome sequence analysis of Nitrososphaeragargensis, a soil AOA revealed the presence of heavy metal resistance genes (Spang et al., 2012). However, information pertaining to the specific mechanisms that confer metal resistance in AOA remains ambiguous due to limited cultivated members of the AOA cluster (He et al., 2012).
Soil PNR was significantly inhibited by the amended heavy metals. These results were consistent with earlier studies where a significant reduction of PNR by heavy metals such as $\mathrm{Hg}$, $\mathrm{Zn}$ and $\mathrm{Cu}$ was noticed (Li et al., 2009; Liu et al., 2010; Smolders et al., 2001; Vasileiadis et al., 2012). In the present study, soil PNR was fitted well with the logistic model $(p<0.05)$, suggesting that the inhibition of ammonia oxidation by heavy metals could be predicted with dose response relationship in toxicology studies. Higher EC 50 
values of $\mathrm{As}$ and $\mathrm{Cu}$ to soil PNR was noticed in $\mathrm{HZ}$ soils. This could be explained by the fact that relatively $\mathrm{HZ}$ soil has higher contents of clay and organic matter than RA soils. Higher organic matter and clay content reduce the bioavailability of heavy metals resulting in amelioration of metal toxicity. The effect of combined metal treatment $(\mathrm{As}+\mathrm{Cu})$ has shown a major negative impact $(p<0.05)$ on all the microbiological parameters measured than the single treatment (As or $\mathrm{Cu}$ ). This could be due to the complex interaction of combined metals in the acidic soils which may influence the metal bioavailability, and toxicological modes of action (Spurgeon et al., 2010).

Even at high concentrations of As ( $70 \mathrm{mg} \mathrm{kg}^{-1}$ dry soil), $\mathrm{Cu}$ (500 $\mathrm{mg} \mathrm{kg}^{-1}$ dry soil) and As $+\mathrm{Cu}$ (As-70 and Cu-500 $\mathrm{mg} \mathrm{kg}^{-1}$ dry soil), the DGGE based AOA-amoA gene community did not change in the acidic soils. These results were in accordance with previous observations where no major difference of AOA-amoA gene DGGE patterns was obtained in $\mathrm{Zn}$ contaminated soils (Mertens et al., 2009; Vasileiadis et al., 2012). However, there is an increasing evidence suggested that DGGE based microbial communities may be limited by co-migration of different sequences to the same position or biased detection of predominant species, resulting in an underestimation of the microbial diversity (Nannipieri et al., 2003). Therefore, we have further evaluated and confirmed DGGE based AOA community results with 4 distinct AOA-amoA gene clone library sequencing analysis. Earlier, AOA-amoA gene phylogenetic analysis showed that group $1.1 \mathrm{~b}$ was the major AOA in acidic soils (Gubry-Rangin et al., 2011; Nicol et al., 2008) and were found to be predominant in the ammonia oxidation of strongly acidic soils (Yao et al., 2011; Zhang et al., 2012). Similar results were observed in this study, where all the 400 putative AOA$a m o A$ gene sequences were affiliated to soil and sediment groups of $1.1 \mathrm{~b}$ among which cluster-III was found to be predominant. We did not find any AOA-OTUs affiliated to group 1.1a (marine lineage) or group 1.1a-associated in these soils. Therefore, the present results indicate a possible potential role of Thaumarchaeota group1.1b (particularly Cluster-III) in AO of heavy metal polluted acidic soils.

Heavy metals adversely affect soil biological processes. When compared to control soil, the reduction in soil PNR could be attributed to significant reduction $(p<0.05)$ in amoA gene copy numbers. However, we must interpret these results cautiously because the measured nitrification activity reflects the nitrification rate at saturating substrate concentrations. Further, soil AOA and $A O B$ responses were measured after "fresh" additions of heavy metals under a 10 week incubation period, thus reflecting acute toxicity, rather than long-term chronic toxic effects of As and $\mathrm{Cu}$ on soil ammonia oxidizers. Heavy metal induced structural changes in ammonia oxidizers community may occur in long-term As and $\mathrm{Cu}$ polluted soils. So that, further field research is required for better understanding of soil nitrification dynamics and the relative contributions of AOA and AOB to ammonia oxidation in long-term As and $\mathrm{Cu}$ polluted acidic soils.

\section{Conclusions}

The present study shows a direct toxic effect of As and $\mathrm{Cu}$ on microbial ammonia oxidizing activity in acidic alfisols. Soil ammonia oxidizing microbes seems much vulnerable to stress of combined As and $\mathrm{Cu}$. The effect of $\mathrm{As}$ and $\mathrm{Cu}$ on AOA community structure was not significantly different from the control soil. Sequencing and phylogenetic analysis of $a m o A$ gene revealed that the Thaumarchaeal-AOA group 1.1b was the only AOA in oligotrophic acidic soils and provide further importance of this group in ammonia oxidation of heavy metal polluted soils. Our results suggest that soil contamination by $\mathrm{As}$ and $\mathrm{Cu}$ may have a significant negative impact on soil $\mathrm{N}$-transformations and corresponding soil fertility.

\section{Acknowledgements}

This work was supported by the National Natural Science Foundation of China (41201523) and the Academy of Sciences for the Developing World (TWAS), Trieste, Italy and Chinese Academy of Sciences (CAS), Beijing, China under the scheme "TWAS-CAS fellowship programme for postgraduate research" to GS for the year 2010.

\section{Appendix A. Supplementary data}

Supplementary material related to this article can be found, in the online version, at http://dx.doi.org/10.1016/j.apsoil. 2014.01.011.

\section{References}

Adriano, D.C., 2001. Trace Elements in the Terrestrial Environments: Biogeochemistry Bioavailability, and Risks of Metals, second ed. Springer-Verlag, New York NY.

Brandt, K.K., Petersen, A., Holm, P.E., Nybroe, O., 2006. Decreased abundance and diversity of culturable Pseudomonas spp. populations with increasing copper exposure in the sugar beet rhizosphere. FEMS Microbiol. Ecol. 56, 281-291.

Chan, Y.K., McCormick, W.A., Ma, B.L., 2013. Effects of inorganic fertilizer and manure on soil archaeal abundance at two experimental farms during three consecutive rotation-cropping seasons. Appl. Soil Ecol. 68, 26-35.

Chen, Y., Xu, Z., Hu, H., Hu, Y., Hao, Z., Jiang, Y., Chen, B., 2013. Responses of ammonia-oxidizing bacteria and archaea to nitrogen fertilization and precipitation increment in a typical temperate steppe in Inner Mongolia. Appl. Soil Ecol. 68, 36-45.

Chodak, M., Gołębiewski, M., Morawska-Płoskonka, J., Kuduk, K., Niklińska, M., 2013. Diversity of microorganisms from forest soils differently polluted with heavy metals. Appl. Soil Ecol. 64, 7-14.

Dai, J., Becquerb, T., Rouiller, J.H., Reversat, G., Bernhard-Reversat, F., Lavelle, P., 2004 Influence of heavy metals on $\mathrm{C}$ and $\mathrm{N}$ mineralisation and microbial biomass in Zn-, Pb-, Cu-, and Cd-contaminated soils. Appl. Soil. Ecol. 25, 99-109.

De Boer, W., Kowalchuk, G.A., 2001. Nitrification in acid soils: micro-organisms and mechanisms. Soil Biol. Biochem. 33, 853-866.

Di, H.J., Cameron, K.C., Shen, J.P., Winefield, C.S., O'Callaghan, M., Bowatte, S., He, J.Z., 2009. Nitrification driven by bacteria and not archaea in nitrogen-rich grassland soils. Nat. Geosci. 2, 621-624.

Francis, C.A., Roberts, K.J., Beman, J.M., Santoro, A.E., Oakley, B.B., 2005. Ubiquity and diversity of ammonia oxidizing archaea in water columns and sediments of the ocean. PNAS 102, 14683-14688.

Frey, B., Pesaro, M., Rudt, A., Widmer, F., 2008. Resilience of the rhizosphere pseudomonas and ammonia-oxidizing bacterial populations during phytoextraction of heavy metal polluted soil with poplar. Environ. Microbiol. 10, 1433-1449.

Gabriel, J.L., Chong, P.L.G., 2000. Molecular modeling of archaebacterial bipolar tetraether lipid membrane. Chem. Phys. Lipids 105, 193-200.

Gubry-Rangin, C., Hai, B., Quince, C., Engel, M., Thomson, B.C., James, P., Schloter, M. 2011. Niche specialization of terrestrial archaeal ammonia oxidizers. PNAS 108 21206-21211.

He, J.Z., Hu, H.W., Zhang, L.M., 2012. Current insights into the autotrophic thaumarchaeal ammonia oxidation in acidic soils. Soil Biol. Biochem. 55, 146-154.

He, J.Z., Shen, J.P., Zhang, L.M., Zhu, Y.G., Zheng, Y.M., Xu, M.G., Di, H.J., 2007. Quantitative analyses of the abundance and composition of ammonia-oxidizing bacteria and ammonia-oxidizing archaea of a Chinese upland red soil under long-term fertilization practices. Environ. Microbiol. 9, 3152-3152.

Kandle, O., König, H., 1998. Cell wall polymers in archaea (archaebacteria). Cell. Mol. Life Sci. 54, 305-308.

Kemnitz, D., Kolb, S., Conrad, R., 2005. Phenotypic characterization of rice cluster III archaea without prior isolation by applying quantitative polymerase chain reaction to an enrichment culture. Environ. Microbiol. 7, 553-565.

Khan, S., Hesham, A.E.L., Qiao, M., Rehman, S., He, J.Z., 2010. Effects of Cd and Pb on soil microbial community structure and activities. Environ. Sci. Pollut. Res. 17 288-296.

Könneke, M., Bernhard, A., de la Torre, J.R., Walker, C.B., Waterbury, J.B., Stahl, D.A., 2005. Isolation of an autotrophic ammonia-oxidizing marine archaeon. Nature 437, 543-546.

Kurola, J., Salkinoja-Salonen, M., Aarnio, T., Hultman, J., Romantschuk, M., 2005 Activity, diversity and population size of ammonia oxidising bacteria in oilcontaminated land farming soil. FEMS Microbiol. Lett. 250, 33-38.

Lee, S., Cho, K., Lim, J., Kim, W., Hwang, S., 2011. Acclimation and activity of ammoniaoxidizing bacteria with respect to variations in zinc concentration, temperature and microbial population. Bioresour. Technol. 102, 4196-4203. 
Leininger, S., Urich, T., Schloter, M., Schwark, L., Qi, J., Nicol, G.W., Prosser, J.I., Schuster, S.C., Schleper, C., 2006. Archaea predominate among ammonia-oxidizing prokaryotes in soils. Nature 442, 806-809.

Li, X., Zhu, Y.G., Cavagnaro, T.R., Chen, M., Sun, J., Chen, X., Qiao, M., 2009. Do ammonia-oxidizing archaea respond to soil $\mathrm{Cu}$ contamination similarly as ammonia-oxidizing bacteria? Plant Soil 324, 209-217.

Liu, Y.R., Zheng, Y.M., Shen, J.P., Zhang, L.M., He, J.Z., 2010. Effects of mercury on the activity and community composition of soil ammonia oxidizers. Environ. Sci. Pollut. Res. 17, 1237-1244.

Lone, M.I., He, Z., Stoffella, P.J., Yang, X., 2008. Phytoremediation of heavy metal polluted soils and water: progresses and perspectives. J. Zhejiang Univ., Sci., B 9, 210-220.

Meharg, A.A., Hartley-Whitaker, J., 2002. Arsenic uptake and metabolism in arsenic resistant and nonresistant plant species. New Phytol. 154, 29-43.

Mertens, J., Broos, K., Wakelin, S.A., Kowalchuk, G.A., Springael, D., Smolders, E., 2009 Bacteria, not archaea, restore nitrification in a zinc-contaminated soil. ISME J. 3 916-923.

Nannipieri, P., Ascher, J., Ceccherini, M.T., Landi, L., Pietramellara, G., Renella, G. 2003. Microbial diversity and soil functions. Eur. J. Soil Sci. 54, 655-670.

Nicol, G.W., Leininger, S., Schleper, C., Prosser, J.I., 2008. The influence of soil pH on the diversity, abundance and transcriptional activity of ammonia oxidizing archaea and bacteria. Environ. Microbiol. 10, 2966-2978.

Nyberg, K.A., Enwall, K., Schnürer, A., Sundh, I., Hallin, S., 2012. Response of induced perturbation on replicating $\beta$-proteobacterial ammonia-oxidizing populations in soil. Microb. Ecol. 63, 701-709.

Ollivier, J., Wanat, N., Austruy, A., Hitmi, A., Joussein, E., Welzl, G., Munch, J.C. Schloter, M., 2012. Abundance and diversity of ammonia-oxidizing prokaryotes in the root-rhizosphere complex of Miscanthus $\times$ giganteus grown in heavy metal-contaminated soils. Microb. Ecol. 64, 1038-1046.

Rotthauwe, J.H., Witzel, K.P., Liesack, W., 1997. The ammonia monooxygenase structural gene amoA as a functional marker: molecular fine-scale analysis of natural ammonia-oxidizing populations. Appl. Environ. Microbiol. 63, 4704-4712.

Schleper, C., Jurgens, G., Jonuscheit, M., 2005. Genomic studies of uncultivated archaea. Nat. Rev. Microbiol. 3, 479-488.

Schloss, P.D., Westcott, S.L., Ryabin, T., Hall, J.R., Hartmann, M., Hollister, E.B., Lesniewski, R.A., Oakley, B.B., Parks, D.H., Robinson, C.J., Sahl, J.W., Stres, B., Thallinger, G.G., Van Horn, D.J., Weber, C.F., 2009. Introducing mothur: open-source, platform-independent, community-supported software for describing and comparing microbial communities. Appl. Environ. Microbiol. $75,7537-7541$

Sheldon, A.R., Menzies, N.W., 2005. The effect of copper toxicity on the growth and root morphology of Rhodes (Chloris gayana Knuth.) in resin buffed solution culture. Plant Soil 278, 341-349.

Shen, J.P., Zhang, L.M., Zhu, Y.G., Zhang, J.B., He, J.Z., 2008. Abundance and composition of ammonia-oxidizing bacteria and ammonia oxidizing archaea communities of an alkaline sandy loam. Environ. Microbiol. 10, 1601-1611.
Singh, N., Ma, L.Q, 2007. Assessing plants for phytoremediation of arseniccontaminated soils. In: Willey, N. (Ed.), Methods in Biotechnology, Vol. 23: Phytoremediation: Methods and Reviews. Humana Press Inc., Totowa, NJ, pp. 319-347.

Smedley, P.L., Edmunds, W.M., Pelig-Ba, K.B., 1996. Mobility of arsenic in groundwater in the Obuasi gold-mining area Ghana: some implications for human health. In: Appleton, J.D., Fuge, R., McCall, G.J.H. (Eds.), Environmental Geochemistry and Health, 113. Geological Society Special Publication, London, pp. 163-181.

Smolders, E., Brans, K., Coppens, F., Merckx, R., 2001. Potential nitrification rate as a tool for screening toxicity in metal contaminated soils. Environ. Toxicol. Chem. 20, 2469-2474.

Spang, A., Poehlein, A., Offre, P., Zumbrägel, S., Haider, S., Rychlik, N., Nowka, B., Schmeisser, C., Lebedeva, E.V., Rattei, T., Böhm, C., Schmid, M., Galushko, A., Hatzenpichler, R., Weinmaier, T., Daniel, R., Schleper, C., Spieck, E., Streit W., Wagner, M., 2012. The genome of the ammonia-oxidizing Candidatus Nitrososphaera gargensis: insights into metabolic versatility and environmental adaptations. Environ. Microbiol. 14, 3122-3145.

Spurgeon, D.J., Jones, O.A.H., Dorne, J.L.C.M., Svendsen, C., Swain, S., Stürzenbaum, S.R., 2010. Systems toxicology approaches for understanding the joint effects of environmental chemical mixtures. Sci. Total Environ. 408, 3725-3734.

Suzuki, M.T., Taylor, L.T., DeLong, E.F., 2000. Quantitative analysis of small-subunit rRNA genes in mixed microbial populations via 5'-nuclease assays. Appl. Environ. Microbiol. 66, 4605-4614.

Tourna, M., Freitag, T.E., Nicol, G.W., Prosser, J.I., 2008. Growth, activity and temperature responses of ammonia-oxidizing archaea and bacteria in soil microcosms. Environ. Microbiol. 10, 1357-1364.

Vasileiadis, S., Coppolecchia, D., Puglisi, E., Balloi, A., Mapelli, F., Hamon, R.E., Daniele D., Trevisan, M. 2012. Response of ammonia oxidizing bacteria and archae to acute zinc stress and different moisture regimes in soil. Microb. Ecol. 64 1028-1037.

von Uexkull, H.R., Mutert, E., 1995. Global extent, development and economic impact of acid soils. Plant Soil 171, 1-15.

Wightwick, A.M., Salzman, S.A., Reichman, S.M., Allinson, G., Menzies, N.W., 2013. Effects of copper fungicide residues on the microbial function of vineyard soils. Environ. Sci. Pollut. Res. Int. 20, 1574-1585.

Yao, H., Gao, Y., Nicol, G.W., Campbell, C.D., Prosser, J.I., Zhang, L., Han, W., Singh, B.K. 2011. Links between ammonia oxidizer community structure, abundance and nitrification potential in acidic soils. Appl. Environ. Microbiol. 77, 4618-4625.

Zhang, L.M., Hu, H.W., Shen, J.P., He, J.Z., 2012. Ammonia-oxidizing archaea have more important role than ammonia-oxidizing bacteria in ammonia oxidation of strongly acidic soils. ISME J. 6, 1032-1045

Zhang, L.M., Offre, P.R., He, J.Z., Verhamme, D.T., Nicol, G.W., Prosser, J.I., 2010. Autotrophic ammonia oxidation by soil thaumarchaea. PNAS 107, 17240-17245.

Zhang, L.M., Wang, M., Prosser, J.I., Zheng, Y.M., He, J.Z., 2009. Altitude ammoniaoxidizing bacteria and archaea in soils of Mount Everest. FEMS Microbiol. Ecol 70, 208-217. 